\title{
Auditing Cases That Made A Difference: Funds Of Funds
}

Bruce A. Struach, The Citadel, USA

Sheila D. Foster, The Citadel, USA

\begin{abstract}
A few fraud cases stand out for the impact they have had on the auditing profession. These cases continue to affect how today's auditing professionals perform the critical job of expressing opinions on financial statements. Names and dates of certain cases appear in nearly all auditing textbooks, but rarely are the stories behind these cases presented. Fund of Funds is an international case so convoluted that it is difficult to tell the players without a score card. It spanned the globe from the Arctic wastelands to European palaces, across the Atlantic to Costa Rican hideaways and then traversed the United States to Hollywood movie lots. It included contact with a couple of US Presidents and a foreign leader thrown in for good measure. Like other "Audit Cases That Made a Difference," Fund of Funds clearly shows students that fraud is not limited to today's corporations and that there is, indeed, little that is new under the sun.
\end{abstract}

Keywords: Auditing; Fraud; Auditor Liability; Fund of Funds

\section{INTRODUCTION}

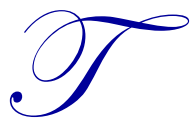

he dollar amounts in the Fund of Funds fiasco seem puny by today's standards, but at the time, the amounts involved were huge and so was the fraud that was taking place. The Securities and Exchange Commission (SEC) went after Robert Vesco for \$224 million, an amount equal to about $\$ 1$ billion today. ${ }^{1}$ The fraud was so convoluted that it is still difficult to tell the players without a score card (Figure 1). It spanned the globe from Arctic wastelands to European palaces, crossed the Atlantic to Costa Rican hideaways, and then traversed the United States to Hollywood movie lots. It included contact with a foreign military leader and a couple of US Presidents thrown in for good measure. While the fraud itself is interesting, the case that Fund of Funds brought against its auditor, Arthur Andersen, is of particular importance. The court findings revealed auditor liability for breach of contract and common law fraud; but first, the fraud.
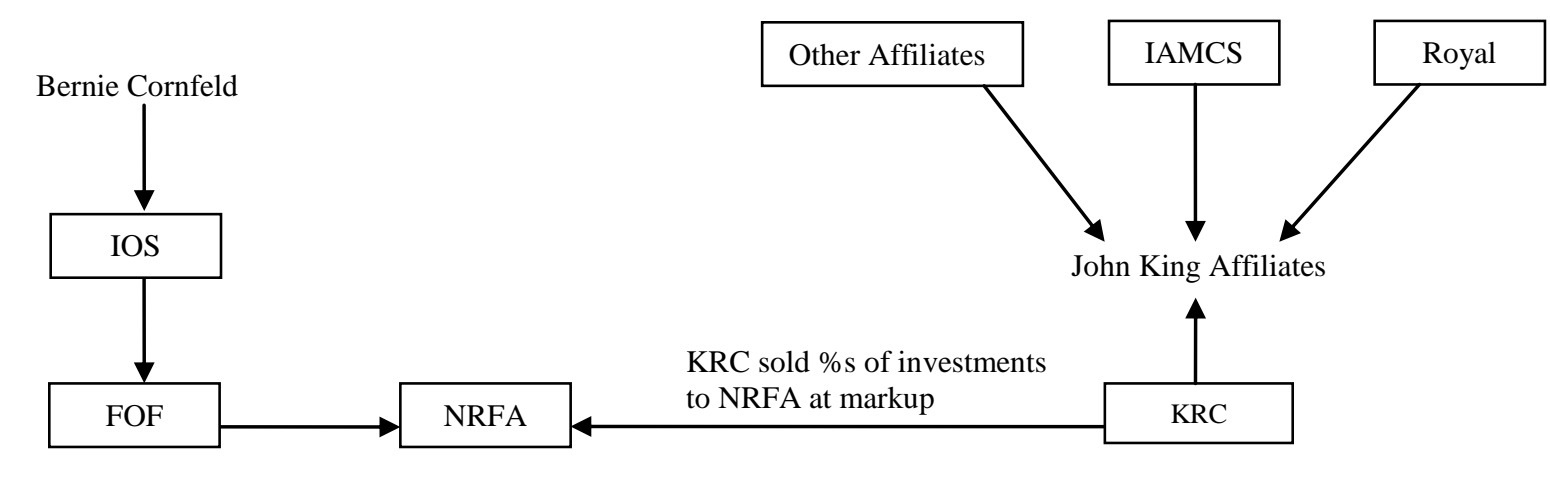

Figure 1: The Players

\footnotetext{
${ }^{1}$ Economist, 2008.

(C) 2012 The Clute Institute http://www.cluteinstitute.com/
} 


\section{A MUTUAL FUND HUSTLER GOES ABROAD}

Short, egg-bald Bernie Cornfeld came from a delusionary family with an actor/movie producer father who left Rumania in the 1920's, and a mother who was convinced that she descended from the Russian Tsarina Catherine the Great.

Cornfeld graduated from Brooklyn College and was employed briefly as a social worker before becoming involved in mutual fund sales. In 1955, he took a trip to Paris, liked the girls he met, and decided to set up shop there. Totally brazen, he placed an ad in the International Herald Tribune to recruit a sales force of expatriate Americans and then convinced the Dreyfus Fund to give him overseas rights to their new product represented by the soon-to-be famous lion symbol. ${ }^{2}$

He might have remained a prosperous salesman, but Cornfeld wanted more and formed his own company, the Investors Overseas Services (IOS). Even though mutual funds were going strong in the US in the late 1950's, they were a new and different instrument in Europe. He took this new concept to American Embassies and the military bases in Europe, North Africa, and the Middle East. Tailoring his pitch to the Cold Warriors, he vowed to turn ordinary folks into a leisure class and beat Marxism at the wealth redistribution game. ${ }^{3}$

\section{GOING OFF-SHORE}

Cornfeld fell in with a Harvard Law cum laude graduate named Edward Cowett who had authored a book on securities regulations, known as Blue Sky laws. Cowett introduced Cornfeld to the wonderful world of off-shore capital. Corporations that had set up in Caribbean tax havens, like Panama or the Bahamas, were, at the time, unregulated or loosely regulated even though they did big business selling in Europe, and certainly no Panamanian court would take an interest in what they did in Geneva or London. Europe had regulatory holes as well. For example, Luxembourg had no securities regulation whatsoever.

Post-WWII affluence had placed amazing amounts of money in the hands of extremely unsophisticated people who could actually be convinced to place their capital in Panama or Tangiers if you talked to them in the soothing language of fiduciary trust. Cornfeld set a trend that was followed by a horde of hustlers, swindlers, and even respectable institutions, like Barclays and the Bank of New York. ${ }^{4}$

Curiously, Cowett noticed that Canada offered the same tax-free benefits as the Caribbean, and he incorporated IOS in Saint John and New Brunswick as a corporation not doing business in Canada. When he discovered that IOS was nothing more than a gang of salesmen, he set about steering the investments. Cowett also set up a separate business for taking small companies public and puffing their stock. He then used IOS funds to take a position in his stocks which moved the price steadily upward. ${ }^{5}$

Finally, in 1962 he was caught and pilloried by the board of IOS. Incredibly, Cornfeld came to his defense, loaned him money to pay off his debts and kept him in the company as general counsel. Cornfeld later would come to regret this. ${ }^{6}$

Since Cowett could no longer direct investments and no one else had a clue how to do it, IOS needed a novel approach. Cornfeld hit upon the idea of a mutual fund that invested purely in the most successful American mutual funds. Thus, in 1962 the Fund of Funds (FOF) was born. ${ }^{7}$

\footnotetext{
${ }^{2}$ Herzog, pp. 54-56.

${ }^{3}$ Ibid., p. 61.

${ }^{4}$ Ibid., p. 54.

${ }^{5}$ Ibid., pp. 57-58.

${ }^{6}$ Ibid., pp. 59-60, p. 55.

${ }^{7}$ Ibid., pp. 61-63.
} 


\section{THE GREAT MONEYCATCHER}

Cornfeld had overcome a youthful stutter through sheer willpower and, as the son of an actor, he knew how to work a crowd. He captivated audiences of salesmen with a line that, in other variations, would become a future mantra for pyramid schemes: "Do you sincerely want to be rich?"8

The FOF jumped from $\$ 1$ million in its first year to $\$ 200$ million by 1965 and came to be nicknamed the "Dollar Crested Moneycatcher." Armed with such leverage, Cornfeld could force New York funds to waive frontload fees while he continued to charge them to his customers. Additionally, IOS developed funds of its own registered in either the Bahamas or the Cayman islands and put FOF money in them. Near the end, the amount invested in New York mutual funds dropped to less than five percent. The rest went into high risk commodities, vacation resorts, movies, and London plays.

Cornfeld filled the powerless FOF board with respectability. Among its members were Edmund "Pat" Brown, two-term Democratic Governor of California, and Pierre Rinfret, economic advisor to three US presidents along with other prominent stockbrokers and lawyers. The IOS board, on the other hand, held all voting rights and was stacked with IOS sales managers, none of whom seemed to have any moral qualms about insider trading, conflicts of interest in investments, or even shorting the company's stock, which several did in the final days. ${ }^{9}$

One of Franklin D. Roosevelt's sons, James Roosevelt, was hired as "Ambassador at Large" and was paid a huge salary to roam the world talking platitudes with heads of state and providing an aura of high statesmanship to Cornfeld's ever-changing "New Deal" and "People's Capitalism" hokum. Roosevelt was only dropped from the payroll after a scandal involving his wife stabbing him in the back with his own Marine Corps bayonet in an argument over his love affair with their son's school teacher. Even so, he remained a figurehead on the IOS board and would later be sued by the shareholders for his incredible incompetency. ${ }^{10}$

\section{BLACK MONEY}

The IOS was a sales-driven company with big overhead. Its plush offices had wall maps dividing the world. Although the sales force grew to 15,000 employees, 90 percent of them were non-producing deadwood who each cost the company $\$ 500$ a year resulting in an annual loss of around $\$ 6$ million. With its already narrow margins, each million lost was the equivalent of increasing sales by approximately $\$ 100$ million, but such a large sales force was essential for Cornfeld's ego. He loved it when they cheered his entry into rooms.

Meanwhile, the growth seemed endless. Unregulated IOS discovered the world of "Black Money" - money that for one reason or another had to be kept secret. It might include funds from such sources as drug trafficking, tax evasion, currency law evasion, or loot from bloody-handed dictators.

The FOF salesmen fanned out across Africa, Asia, the Caribbean, and Latin America while mob money came out of Miami. Wars, revolutions, army mutinies and massacres always produced clients trying to get their assets out of hot spots. The Congo massacres and the Biafran war in Nigeria were kindling to fuel Cornfeld's boys. ${ }^{11}$ They smuggled bags of money out of currency-controlled Latin American countries to the IOS Geneva offices. Since Switzerland had no laws against tax or currency evasion, it was a welcome haven. The Swiss had been creating fake loans of depositor's money since the 1930's when Mafia moneyman Meyer Lansky gave them the idea. ${ }^{12}$

Sales commissions were so high they outstripped the front-load fees from the funds. No one cared because no one was really in charge, except Cornfeld, and he was busy squandering the invested money with both hands

\footnotetext{
${ }^{8}$ Ibid., p. 56.

${ }^{9}$ Ibid., p. 97.

${ }^{10}$ Ibid., PP. 81-82, pp. 90-93.

${ }^{11}$ Ibid., p. 66.

${ }^{12}$ Ibid., pp. 66-69.
}

() 2012 The Clute Institute http://www.cluteinstitute.com/ 
betting that his visionary projects would pay off some impossible amount. $\mathrm{He}$, in fact, was building a Ponzi-style pyramid. The salesmen just had to keep broadening the base of the pyramid which seemed limitless. Sales rose to $\$ 3$ billion by 1969 and IOS was the largest mass of unregulated investment dollars on the planet. ${ }^{13}$

Timing is important in a pyramid scheme since bad news may cause a run on the fund when panicked investors try to redeem their investment. Luckily, Cornfeld had a long lead time because the mutual funds are for retirement and because so much black money had been put with FOF for safe-keeping in the event that someone had to flee a country in flames. One of FOF's schemes was that much of its money would be locked in and could never be claimed because of its truly dirty criminal origins. It was called "Mug's Money" and was estimated at around \$200 million.

Any con artist will claim you have to look rich before a sucker will trust you with his money. Whether the act is rational or if it is for mere grandiosity, the need of a con artist is not clear. Nonetheless, Cornfeld certainly liked to spend. Not only did he move his headquarters to a $13^{\text {th }}$ century chateau in Haute Savoie, France, near the Swiss border, but he also had apartments in Paris, London, and New York, and a lake front villa in Geneva. ${ }^{14}$

Although he never drank alcohol, smoked tobacco, or engaged in drugs, silky Cornfeld liked sexual activity due to his fear of being alone. An endless string of girlfriends were willing to help him with the loneliness problem by being extremely attentive as long as he was lavishing money on them. ${ }^{15}$ His name was linked with such beauties as Victoria Principal (of television's night-time soap opera series "Dallas") and Princess Ira of Furstenberg. ${ }^{16}$

The 60's were the era of "Swinging London," and Cornfeld dressed the part. In addition to wearing outlandish "mod" velvet suits, mauve shirts, and floppy neckties, he also grew a beard and a long fringe hair skirt around his bald head. He drank Coca-Cola with dinner and decorated his mansion which was once owned by Douglas Fairbanks with velvet, golden fittings and busts of Roman emperors. Even the toilets were modified Louis XVI armchairs. ${ }^{17}$ It would follow that he surrounded himself with movie industry people. ${ }^{18}$

It was also the era of Hugh Hefner and the International Playboy clubs and resorts. Cornfeld had money to invest and soon became pals with Hefner. He did his best to imitate the Playboy mansion- style non-stop parties with groupies, celebrities, and hangers-on. Heidi Fleiss, later know as the "Hollywood Madam," began her harlot's career at age nineteen as one of Cornfeld's girls. Likewise Donna Rice, whose later public affair with Gary Hart wrecked his run at the Presidency, spent time with Cornfeld. ${ }^{19}$

\section{PUBLIC OFFERING FEVER}

In 1969, at age 42 the foppish Cornfeld had his own line of champagne, the Chateau Pelly de Cornfeld. While he was building a complex as the headquarters for the coming the 1972 Munich Olympic Games, he consorted with Hugh Hefner in Acapulco over an IOS-Playboy hotel. Each brought in a bevy of bosomy girls. Not only did he share his thoughts at important business forums, but he also met with the Pope seeking his blessings for sales in Latin America. They even had a chat about the white velvet on the walls.

Cornfeld and his buddies had always planned on cashing out through the sale of their stock options. By doing so, he could get on with his Oleg Cassini and Guy Laroche boutiques, movie production, and other visionary projects. He did a trial offering in Canada that proved successful, ${ }^{20}$ and sparked a glint in Cornfeld's eyes. Since Canada was a dinky market and IOS was at its height with a million customers and $\$ 3$ billion in the funds, he decided to make a major public offering in Europe the following year.

\footnotetext{
${ }^{13}$ Ibid., p.69.

${ }^{14}$ Ibid., p. 77.

${ }^{15}$ Ibid., pp. 50, 72.

${ }^{16}$ Wikipedia.

${ }^{17}$ Herzog, pp. 94-95.

${ }^{18}$ Wikipedia.

${ }^{19}$ Herzog, p. 73.

${ }^{20}$ Ibid., pp. 95, 85, 67.
} 
The $\$ 110$ million offering was the largest in European history and the third largest in world history. Offered at $\$ 10$, shares quickly rose to $\$ 19$. The IOS insiders pocketed $\$ 55$ million from the sale of their own shares with Cornfeld's take being $\$ 8.2$ million. Another $\$ 50$ million went into the IOS coffers. ${ }^{21}$ Cornfeld figured the stock would climb even higher if they could post a good year-end performance, which is what led him to a fateful meeting with John M. King.

\section{THE LOUD-MOUTHED BULL ELEPHANT}

John McCandish King suffered childhood asthma and spent his formative years in bed learning to knit and reading everything he could. Even though he attended a few colleges, he was not a graduate of any. However, he was an aide to Harold Stassen at the 1945 San Francisco conference that organized the UN. On and off, he flirted with the Methodist ministry and was even elected and served three terms to the Illinois state legislature. ${ }^{22}$ At age 25 , he hit a wildcat oil strike and then an unheard of 15 more in a row. King Resources became a major independent and was soon using 15 percent of the world's drilling rigs. ${ }^{23}$

Never what you would call an introvert, "Big John" to some and "Gas Bag" to others, King told everyone who would listen that he was one of seventy-five "oil finders" in the world, men with a near-mystic ability to see into the earth. Business magazines will always fawn over success and Forbes guessed his wealth at $\$ 300$ million while Dun's Review opined that he had made his fortune faster that John D. Rockefeller.

King was age 41 at the time of our story, six-foot-three, 250 pounds, egg-bald, and clad in cowboy boots, hats and buckles. He had six homes, an air fleet, and a stretch limo he liked to use for hunting. He was constantly on the road and on the phone. His favorite painting was of a bull elephant charging straight at the viewer, ears out, trunk up trumpeting its anger. ${ }^{24}$ The truth was that King's grasp of the oil business was pretty feeble. In reality, he was a mutual fund salesman, principally of petroleum fund "tax shelters" for the little man. This is what brought Western he-man John King into a meeting with designer-clad Bernie Cornfeld. ${ }^{25}$

King needed endless cash for his oil drilling and IOS was the "Dollar-Crested Moneycatcher". King didn't care for troublesome paperwork and liked to do business Western style - on a handshake. Of course, this suited Cornfeld just fine. Oil, uranium, gold, silver, copper, and diamonds all sounded so lush with boundless money possibilities. ${ }^{26}$

Despite the solemn promise to his investors that he would only put money in mutual funds and never anything as illiquid as mineral exploration, Cornfeld shoved an initial \$10 million across the table to King. Another $\$ 100$ million would soon follow. The IOS's Fund of Funds became King's biggest customer. ${ }^{27}$

King, in turn, sold FOF dry holes and an abandoned gold-mining venture on Vancouver Island that he claimed was worth $\$ 900$ million. He regularly boosted values by 1,000 percent over what he had paid for them. After all, big-ego John had the magic eye for a super deal and he was selling them only for what was "fair.",28

The discovery of Alaskan oil attracted King to the Arctic. He bought drilling permits from the Canadian government for mammoth areas of geography. In 1969, he sold FOF an undivided one-half of King Resources' Canadian permits in an area somewhere north of Baffin Island for $\$ 11$ million. It was 11 million acres, an area about the size of the state of New York. ${ }^{29}$ And what a deal it was for King and Cornfeld. If any money was made, along with his retained 50 percent of the property, King would receive 12.5 percent of FOF's profits. In addition,

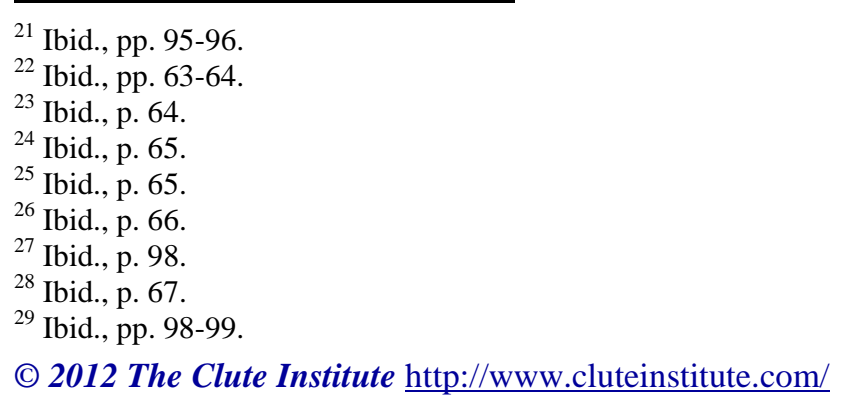


IOS would get a 10 percent "performance fee" as financial advisor to FOF. ${ }^{30}$

Much of it was at excessive underwater depths beneath shifting pack ice known as "whale pastures" in the oil business. Drilling was impossible there, but nobody at FOF bothered to read much - neither about oil drilling under ice or about the deal just made. Consequently, they missed the fact that Canadian permits carried an obligation that one must actually drill for oil. Otherwise, FOF would have to pony up another $\$ 20$ million the next year or the permits became void. ${ }^{31}$

\section{ARTHUR ANDERSEN STEPS IN DOO-DOO}

Arthur Andersen \& Co. (AA) was the auditor representing both King and IOS. Among some of the other stunts by King was the selling of FOF oil and gas exploration permits to which he had no claim. Incredibly, Arthur Andersen was forbidden by FOF to verify the permits or examine the surveys upon which they were valued, yet AA continued to work for both sides.

Big-mouthed John King claimed the Arctic drilling rights were worth $\$ 3$ billion. Cornfeld readily agreed and said that they needed to be revalued on the books. Actually he wanted the stock to jump in value so that IOS would get a management fee for its role in the increased value. ${ }^{32}$ Andersen declared that there was no way to verify a value above the sale price unless there was an oil strike or a new sale to a reputable company. ${ }^{33}$ To expedite this write-up, King promptly gathered some of his buddies together, promised they would never have to pay a dime, and had them "buy" a piece of the investment. ${ }^{34}$ This was never an "arm's length" transaction in which a serious buyer came in and negotiated a sale, but rather a sale of permits mainly in unsuitable, non-drillable deep waters. Based on these "sales," IOS then claimed that FOF's value had jumped \$107 million. Concomitantly, an IOS press release in December 1969 announced this fabulous event without ever revealing the purchasers, the method of payment, nor the location of the permits. ${ }^{35}$

The IOS took a $\$ 10$ million "performance fee" from FOF as though through its efforts it had increased the value of the investment. This sleight of hand was the only IOS profit for the year 1969. It took the fee up front while FOF received only $\$ 600,000$ from the sale. The rest of the FOF money was supposedly to be paid over the next six years, but it never was. The assets sold were, in fact, transferred to the books of King Resources. When alert money managers could see that something was wrong with IOS's profit, FOF fund-holders began redeeming their shares for cash.

\section{THE END DRAWS NIGH}

Six months later the pyramid ran out of steam - sales were down 60 percent; projected profits vanished; the cash position was close to zero; and the $\$ 52$ million from the public offering had vanished. Where had it all gone? The officers would not give the IOS Board an accounting. Finally, the board had had enough of Cornfeld's ego and extravagance. Panicked directors met in Geneva to demand answers. It was then that Ed Cowett admitted he had spent all their available cash supporting the value of the stock which had nonetheless plummeted to $\$ 8$. He also confessed that countless millions had been frittered hither, thither, and yon. Cornfeld was stunned that Cowett had effectively accomplished this behind his back. ${ }^{36}$

The stock fell to $\$ 5$ as the bad news leaked out. Then IOS insiders made it worse by selling off their shares. Consequently, Cornfeld began selling to cover the debt on his airplanes. ${ }^{37}$ When the banks called margin loans on all IOS stock, IOS immediately reacted and began selling big blocks of American stocks to meet client

\footnotetext{
${ }^{30}$ Ibid., p. 99.

${ }^{31}$ Ibid., p. 98.

${ }^{32}$ Ibid., p. 76.

${ }^{33}$ Ibid., p.77.

${ }^{34}$ Ibid., p. 77.

${ }^{35}$ Ibid., p.77.

${ }^{36}$ Ibid., p. 86.

${ }^{37}$ Ibid., pp. 88-89.
} 
redemptions. At this point, Wall Street feared a major crash would impact capital markets. ${ }^{38}$

No one legit wanted to bail out a company with no internal controls and scarcely an employee who could actually read a balance sheet. The press began to focus on Cornfeld's lurid behavior, especially the Acapulco meeting with Hugh Hefner. Since the company was losing \$1 million a month, once again IOS began selling stock to cover redemptions. In an increasing frenzy, the board fired Cornfeld who sat sulking in his Geneva lakefront villa daydreaming of restoring his fantasy to its glory. ${ }^{39}$

John King was also in trouble. His company was floating purely on investments from IOS. Hence, he put forward an extensive plan to bring IOS out of the off-shore world and into the US. His intention was to put its sales force in the business of selling oil mutual funds. Curiously, it might have worked as oil prices were soon to rise sharply with the formation of OPEC..$^{40}$ However, the problem was that King had no money for the bail-out. No one would lend and his bankers began calling his loans. In short order, he was ruined having lost everything. He blamed it on a Rockefeller conspiracy. Standard Oil was terrified of the growing power he claimed. He spent a year in jail for phony "arm's length" transactions and would later suffer a fall from a horse that put a stick through his neck. Even though he survived the tragedy, a series of strokes wrecked his memory. ${ }^{41}$ The IOS desperately needed a white knight but, unfortunately, found the exact opposite in Robert Vesco.

\section{THE BOOTSTRAP BOOR}

Robert (Bob) Vesco, son of an auto assembly line worker at Chrysler, made a hash of school before starting a small body shop. Throughout his life, he would be marked by blue-collar crudeness and the table manners of a pig. He impregnated his high school sweetheart and married her, but even so, he was determined to make his mark in life. She was a farm girl from Bad Axe, northern Michigan, bright-eyed, bubbly and adoring most of their married life and, in the end, she accepted a life on the lam with him. ${ }^{42}$

Vesco took a job at Reynolds Aluminum and made his first mark in the field of ethics by designing a onepiece aluminum automobile grill. It superseded the multi-paneled steel grill, costing the customer three times as much in repairs after a collision because the entire grill, rather than a part of it, would have to be replaced. This gained him a promotion to headquarters in New York City. ${ }^{43}$

It was 1959 , the age of the man in the gray flannel suit, when Vesco appeared to be the big corporate success to his wife and three children with their lovely home in the Jersey suburbs, but the ambitious Vesco was determined to be his own master. He quit Reynolds and cut a deal with a company with a dormant aluminum press. His idea was for the company to man the press while he would find the buyers for its product. He called his company Aluminum Services Incorporated and his office was in a corner of the outfit that owned the press. Although it was pretty shabby, Vesco's ideas were not. He was a visionary and America was entering the go-go 1960 's - the era of conglomerates. ${ }^{44}$

Taking off with his first conglomerate, Vesco stumbled across Captive Seal, a puny, struggling enterprise with twenty minimum-wage workers and one asset - a patent on a gasket used in airplanes. Here was his opportunity to be the venture capitalist to get financing for expansion and then, in turn, sell to a large corporation. ${ }^{45}$ In the search for investors, he came across Malcolm McAlpin, an old-money 1920's Princeton graduate and Wall Street broker. These very different men developed an odd working relationship but, nonetheless, managed to launch Captive Seal. McAlpin introduced Vesco to Cryogenics, Inc., a company still listed on the stock exchange but merely a shell with no assets at the time. Buying Cryogenics and merging his two companies allowed Vesco to sell

\footnotetext{
38 Ibid., p.111.

${ }^{39}$ Ibid., p. 125.

${ }^{40}$ Ibid., pp. 95, 97.

${ }^{41}$ Ibid., pp. 77, 100.

${ }^{42}$ Hutchinson, pp. 10-11.

${ }^{43}$ Ibid., p. 13.

${ }^{44}$ Ibid., pp. 14-15.

${ }^{45}$ Ibid., pp. 16-17.
}

(C) 2012 The Clute Institute http://www.cluteinstitute.com/ 
shares in Captive Seal without listing it with the SEC. He called the new company International Controls Corporation (ICC) and Vesco used it to raise yet more money that soon enabled him to bring in two more aircraft parts companies. ${ }^{46}$

In the lifestyle sphere, Vesco moved up to Mercedes and Buick with vanity license plates and built a "company bungalow" in Denville, New Jersey, which only he and his family used. This expanse of 500 acres included a swimming pool, a tennis court, and stables. Even though he attired himself in black mohair suits, sported greased-back hair, long Elvis-style sideburns and a pencil mustache, he continually appalled the public with his rudeness and primitive table manners. Some even claimed he wore clear fingernail polish. ${ }^{47}$

When he pulled off a hostile take-over of another aircraft parts company far bigger than his own, his admirers began calling him "the Bootstrap Kid." At age 33, he had acquired a \$100 million-a-year company with a $\$ 6$ million-a-year shell. Since America had put a man on the moon in 1969, Vesco began imagining himself in the aerospace industry.

He rented white tie and tails for a $\$ 10,000$-a-plate political dinner party and inserted himself in a photo with, at that time, President Lyndon Johnson and Richard Nixon. After dinner, he met Nixon and became transfixed. Over the coming years, he paid a disputed amount into the Nixon slush fund and would always claim to have had strength in the White House. At the end of his frauds, however, he tried to cast himself as a victim of a Nixon witch hunt.

In reality, all of Vesco's companies were losers and he didn't have a clue as to how to turn them around. All he knew was debt financing and tricky bookkeeping. Wall Street started to wake up to this reality. Soon he desperately needed $\$ 2$ million to pay debt service on his conglomerate. Then he remembered that IOS was a money machine and he remembered Ed Cowett - one of the insiders.

\section{VESCO SLIMES INTO IOS}

Cornfeld's last moment of glory was the announcement of the London public offering, carried out in grand style in a ballroom of a Geneva hotel. The sales force cheered Cornfeld to the rafters as he used space explorer clichés and predicted they would all become millionaires.

Naturally the sales force rushed to borrow money to buy stock, but that was not enough for Cornfeld. He ordered the issuance of IOS stock to every single employee, from executive to clerk, at the offered price and insisted that corporate money be loaned to help them pay for it. Swiss criminal law considers this abetting speculation beyond an individual's means. It carries a prison sentence which Cornfeld would face four years later.

Ultimately IOS only received $\$ 50$ million from the offering with the rest going to insiders, and that money went to staunch bleeding and into Cornfeld's wild spending. Ten months later, the shares were coming down in price from a high of $\$ 19$ to below the $\$ 10$ issuing price. Unfortunately, a dreadful loss was predicted for 1970 and those who had purchased on borrowed money now stood to lose everything.

By the time Cornfeld was removed as CEO, every big financial consortium had refused to aid IOS. Among these were Rothschild, Solomon Brothers, Smith Barney, Merrill Lynch, Mellon, Loeb Rhoades - in essence, everyone. The board was having a collective nervous break-down. Absurdly, Cornfeld was throwing tantrums and organizing a proxy fight while still having salami flown in to him from New York. The stock sank to $\$ 3$. Fears were escalating because European investors could lose confidence in American stocks (not that FOF was really that much into stocks) and because that capital flow to the US could drop.

Under such conditions, the board was reduced to crawling to a sleaze like Vesco who was brought in by one of the directors. Since Vesco's empire was a dud, he needed to keep growing to stay ahead of his own creditors. Acquiring IOS would be a good leap.

\footnotetext{
${ }^{46}$ Ibid., pp. 16, 24.

${ }^{47}$ Ibid., p. 37, and Herzog, pp. 16-20.
} 
Meanwhile, in his villa, Cornfeld plotted with IOS salesmen, a former Elvis Presley groupie, and two Playboy bunny sisters to save the IOS. With typical Cornfeld showmanship, he showed up on a houseboat surrounded by leggy, bikini-clad lovelies and made a proposal to the board for a come-back.

It was based on a fantasy he called "Cinema City" which would be located near Palm Springs and would become the movie capital of the world. The board laughed at him, sending him into a fury. ${ }^{48}$

Cornfield and Vesco met but did not like each other. When Vesco displayed his socially unacceptable table manners, Cornfeld called him a "hoodlum." 99

Without delay, Vesco approached the IOS board with a rescue plan. He offered a \$5 million loan to IOS under the auspices that he would take operational control of the company and turn it around in a year. If he failed to do so, he would get $\$ 3.5$ million plus one third of the company's stock. It was an absurd offer, but the board was made up of unqualified salesmen who could not read a financial statement, not to mention some ill-equipped figureheads, like James Roosevelt who owed IOS for loans. Vesco pretended that Bank of America, along with the Prudential Insurance Company, was backing him and with his influence, they would surely invest. No evidence of this partnership was ever produced. ${ }^{50}$ In fact, Vesco did not have $\$ 5$ million. He had already been looking for $\$ 2$ million needed for his own company. Nonetheless, he persuaded Ed Cowett to place IOS money with a Bahamian bank that then loaned it to him, thus allowing IOS to fund its own takeover. Given that IOS had been spending "invested" money for years, it did not really need $\$ 5$ million. ${ }^{51}$

A month later, Vesco narrowly took total control of the company in a proxy fight. He began paying debts on his aircraft conglomerate with IOS money and travelled the world seeking deals in a sea-going yacht and a Boeing 707 called "Big Bird." Since Vesco was a man of the '70's, it would follow that the plane had a disco dance floor with strobe lights. ${ }^{52}$

Vesco had hazy plans of becoming a world financial power with an entourage that included Don-Don Nixon, nephew of Richard Milhous Nixon. He entertained international bankers with troupes of prostitutes, Dom Perignon champagne, and Iranian caviar. They took his sleazy hospitality and laughed at him. ${ }^{53}$

In less than a year, the SEC began an investigation of Vesco and twenty other businessmen for securities fraud and looting over $\$ 224$ million from IOS. Vesco fled the country to Costa Rica and other parts unknown. ${ }^{54}$ Two hundred thousand dollars cash of IOS money went to CREEP, the Committee to Reelect the President (Nixon), which was involved in espionage and burglary. This was an illegal corporate campaign contribution and Vesco would later try to use it, without success, as leverage against the White House to squash the SEC investigation. ${ }^{55}$

The Vesco money trail would later lead to Commerce Secretary Maurice Stans and Attorney General John Mitchell who were indicted for obstruction of justice and perjury. Both were acquitted, but the stench of Watergate became entwined with the Vesco looting. ${ }^{56}$

Vesco was briefly jailed in Switzerland for stealing someone else's shares to vote them in the IOS proxy fight. As soon as he was released on bail he fled the country. At this time, the SEC began investigating the aircraft conglomerate. Failing to become a world financial power, Vesco decided to become a giant among international swindlers. Unsurprisingly, he made the decision to take the money and run. ${ }^{57}$

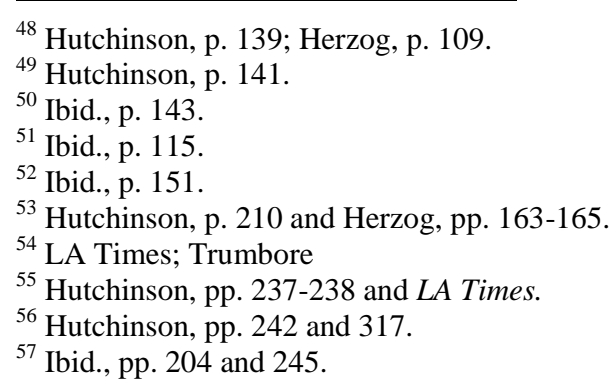

(C) 2012 The Clute Institute http://www.cluteinstitute.com/ 


\section{THE LAST ACT}

The FOF began "investing" in Caribbean and Central American companies. When the newly hired auditors, Coopers \& Lybrand, attempted to access documentation of these investments but were denied, they wisely resigned as auditors for Vesco's International Controls, as well as IOS. ${ }^{58}$

With his furtive deception covered, Vesco diverted IOS' assets into a mare's nest of bank accounts, dummy companies, and off-shore banks. This was done with incredible rapidity, and within months the sales force was idled. It was then that IOS moved into the hands of court-appointed liquidators. ${ }^{59}$

While Cornfeld had squandered roughly $\$ 500$ million through idiotic investments, overcharging, scalping and gross extravagance, Vesco managed to nab another $\$ 500$ million through his web of conversion and theft. He attempted to control gambling in the Bahamas as well as a shady Middle Eastern bank, but he failed at both. He went to ground in Costa Rica claiming he was a victim of a political witch hunt that was trying to crucify him along with Nixon. After he bought citizenship and spread money around, public opinion in the form of the President Figueres' political opposition, demanded he get out. ${ }^{60}$

He moved to Antigua where pay-offs to officials ran $\$ 10,000$ a month. When the FBI sent a team down to the island, Vesco swiftly escaped on his yacht in screaming gale-force winds. The fugitive and his family went to Mexico, Colombia, and the Nicaragua of the Sandinista revolutionaries. In each place, he promised investments that never materialized. ${ }^{61}$

In a failed attempt to sell the IOS shell to a Spanish group, Vesco made contact with Fidel Castro and, after leaving Costa Rica, was given asylum in Cuba. ${ }^{62}$ He tried his hand at cocaine trafficking and presented schemes for economic warfare against the US. He even attempted deals to breach the American trade embargo. At one point, he was accused of swindling the Cubans on a drug to cure cancer and AIDS and was put under house arrest. Later, it even was rumored that Vesco had tried to use President Jimmy Carter's brother, Billy, to help arrange a deal to sell aircraft to the Libyan government. Finally, after more than three decades on the lam, it was reported that he had died in November 2007. ${ }^{63}$

Cornfeld was arrested by the Swiss and charged with criminal fraud and inciting speculation. Because the Swiss take their reputation as a safe banking haven seriously, they jailed him for eleven months. He managed to make bail with the help of movie stars Tony Curtis and George Hamilton. When he returned to trial, he was acquitted, no doubt, because the IOS paperwork was in such disarray no one could quite figure what exactly had happened. ${ }^{64}$ Ed Cowett filed for bankruptcy and died of a heart attack in 1974 while on an airplane flight. ${ }^{65}$

\section{AND ARTHUR ANDERSEN IS LEFT AS THE DEEP POCKET}

At the time, Arthur Andersen \& Co., one of the "Big Eight" accounting firms, was the auditor for FOF, King Natural Resources (KNR), other King affiliates, and even did work for King himself. ${ }^{66}$ As often happens in cases like this, the only party left with any money is the auditor; consequently, the "injured" parties will look to the auditor to recover their losses. Arthur Andersen was now the perfect target.

An open-ended mutual fund, like FOF, must value its investment portfolio daily. Natural resources present a valuation problem due to their speculative nature and limited market. Properties are carried at cost until a

\footnotetext{
${ }^{58}$ Herzog, p. 183.

${ }^{59}$ Hutchinson, pp. 253 and 257-259.

${ }^{60}$ Herzog, p. 206 and Hutchinson, p. 311.

${ }^{61}$ Herzog, pp. 303, 315, and 333.

${ }^{62}$ Hutchinson, p. 319.

${ }^{63}$ Economist.

${ }^{64}$ Hutchinson, p. 335.

${ }^{65}$ Ibid., p. 343.

${ }^{66} 545$ F. Supp. 1314, 1327.
} 
compelling event, like an oil strike, occurs to require a value change, or a sale of a large percentage of the investment can be sold to a company with a reputation in the field to change the value of the remaining percentage still held. ${ }^{67}$

Arthur Andersen \& Co. had noted two previous sham transactions by King - first, a sale of resource properties to a subsidiary of KNR and second, a circular swap of properties with two companies. In each case, AA saw the transaction as an artificial depiction of property values. The auditors were adamant about the fact that any revaluation for FOF must have been the result of an arm's length transaction. King tried, without success, to get Standard Oil of Indiana to make a buy, but Standard really was not interested in the undersea Arctic oil fields known as "whale pastures." 68 A disappointed King brought in his buddies, who were themselves on the edge of bankruptcy. King either arranged loans for the down payments by the buyer or shoved money their way by using their equipment or by buying oil property from them at an inflated price. ${ }^{69}$

Rather than tell FOF what it knew, Arthur Andersen issued a "subject to" opinion for the shareholders of FOF stating that the company was not competent to appraise the investments and did not express an opinion on the valuations. The FOF sued Arthur Andersen \& Co., but what were the damages?

Savvy investors spotted IOS's weakness when its only profit was the management fee. They cashed in, redeeming their shares at an inflated value following the revaluation. Then IOS ingeniously took out the inflated management fee from the FOF assets. ${ }^{70}$

Andersen contended that the IOS and FOF boards made the decisions, which was a true statement; however, AA claimed those involved were sophisticated businessmen, which was debatable. In fact, the board members were all enamored with King and did not rely on anything Andersen did or said.

Strangely, FOF asked AA to develop a valuation methodology, but AA made no effort to enforce the ground rules it had laid down. The auditors knew that the rules had not been followed as to the percentage of property sold. Neither did AA make an effort to test the arm's length nature of the sale nor ask the buyer anything about side deals. Although AA knew that FOF relied on them, they never told them about the two prior frauds by King, both of which had been affected by side deals that relieved the "buyer" of any real obligation to buy.

\section{IMPACT ON THE PROFESSION}

Ethics can be defined as a set of moral values and principles that govern behaviors. As individuals, we each have a set of such values and principles. Organizations, too, are governed by an ethical code of conduct. Sometimes situations arise in which one ethical principle contradicts another, placing the individual or organization in an ethical dilemma. Such a dilemma arose in the Fund of Funds case.

Under Rule 301 of AICPA Code of Professional Conduct, "[a] member in public practice shall not disclose any confidential client information without the specific consent of the client." The confidentially rule is tempered somewhat by limiting provisions including that "[t]his rule shall not be construed (1) to relieve a member of his or her professional obligations under Rules 202...." Rule 202 states that "[a] member who performs auditing, review, compilation, management, consulting, tax, or other professional services shall comply with standards promulgated by bodies designated by Council."

What happens when rules and actions regarding standards and client confidentially collide?

\footnotetext{
${ }^{67}$ Ibid., 1335 and 1338

${ }^{68}$ Ibid., 1339.

${ }^{69}$ Ibid., 1340.

${ }^{70}$ Ibid. 1344 and 1345.
} 
Because Arthur Andersen was involved with two of the companies, AA had access to information that certainly could have affected its view of the transactions between the parties. Arthur Andersen, in its engagement letters of 1968 (and similarly in 1969), stated:

Our audit work on companies for which we are responsible will consist of examination of the respective balance sheets and statements of net assets and investments as of December 31, 1968, and the related statements of income, surplus and changes in net assets for the year ending in order to enable us to express an opinion on the financial position of the respective entities and the results of their operations. These examinations will be made in accordance with generally accepted auditing standards and will include all auditing procedures which we consider necessary in the circumstances. These procedures will include, among other things, review and tests of the accounting procedures and internal controls, tests of documentary evidence supporting the transactions recorded in the accounts and direct confirmation of certain assets and liabilities by correspondence with selected customers, creditors, legal counsel, banks, etc. While certain types of defalcations and similar irregularities may be disclosed by this kind of examination, it is not designed for that purpose and will not involve the audit of a sufficiently large portion of the total transactions to afford assurance that any defalcations and irregularities will be uncovered. Generally, primary reliance for such disclosure is placed on a company's system of internal control and effective supervision of its accounts and procedures. Of course, any irregularities coming to our attention would be reported to you immediately. ${ }^{71}$

Court documents from the ensuing trial indicate that such information came to, or should have come to, the attention of AA. For example, during the 1968 year-end audit for Fund of Funds, a "Summary of 1968 Sales to Imperial-American Management Company (IAMC), Royal, and IOS" for oil, gas, and mineral interests showed profit as a percent of sales to IAMC (a King affiliate) at 16.8\%; to Royal (another King affiliate) at $37.8 \%$, and to IOS (in actuality, Fund of Funds) at a whopping 62.0\%. This percentage was most likely considerably higher since, according to court documents, five additional transactions with profits of $98.7 \%, 98.6 \% 85.6 \%, 58 \%$, and $56.7 \%$ were omitted from this schedule. Testimony also shows that King had, and AA knew about, a "special inventory" for resale to Fund of Funds. ${ }^{72}$ Likewise, evidence of numerous interoffice and corporate memos regarding difficulties with the values and revaluations of properties were available to the auditors. In testimony, it became clear that on several occasions properties were acquired by KR or its affiliates with a percentage sold to IOS at an inflated ten or twenty times the price on the same day or immediately afterward - something a knowledgeable investor would not do. ${ }^{73}$

However, Andersen did not notify FOF of these facts even though, in a somewhat unique situation, AA's Denver office was simultaneously working on audits for both King and Natural Resources Asset Fund Account (NRFA) for Fund of Funds. The partner-in-charge and manager held the same position for both audits and the records of both companies were shown to have been used in the audit prepared for FOF. Here is AA, sitting in the middle, auditing both companies, and able to see the transaction from both sides. Fund of Funds contended that AA had violated several generally accepted auditing standards including:

\section{General Standards}

- In all matters relating to the assignment, an independence in mental attitude is to be maintained by the auditor or auditors.

- $\quad$ Due professional care is to be exercised in the planning and performance of the audit and the preparation of the report.

\section{Standards of Field Work}

- A sufficient understanding of internal control is to be obtained to plan the audit and to determine the nature, timing, and extent of tests to be performed.

\footnotetext{
${ }^{71}$ Ibid., p. 1327.

${ }^{72}$ Ibid., p. 1314 and 1332.

${ }^{73}$ Ibid., p. 1330.
} 
- $\quad$ Sufficient, competent evidential matter is to be obtained through inspection, observation, inquiries, and confirmations to afford a reasonable basis for an opinion regarding the financial statements under audit.

\section{Standards of Reporting}

- Informative disclosures in the financial statements are to be regarded as reasonably adequate unless otherwise stated in the report. ${ }^{74}$

Arthur Andersen denied that it had breached the terms of its engagement letter and AA never disclosed its doubts about the sales to FOF. Even so, Fund of Funds, Limited (FOF) brought a suit against Arthur Andersen \& Co. (AA) and Arthur Andersen \& Company (Switzerland), one of the then "Big Eight" accounting firms, for violating federal securities laws, for common-law fraud, breach of contracts over FOF's investments in natural resource interests and, in particular, the sale of part of its Canadian Arctic investment. The sale of this investment previously had been used as a basis for "revaluation" of the remainder of that investment's value. The trial began on July 13, 1981.

After a trial lasting nearly two months and another two weeks of deliberation, the jury found AA guilty on several of the charges related to the revaluations. The jury felt "[s]center [could] be shown by AA's actual intent to deceive or defraud, knowledge of the falsity of its representations.... AA disregarded its affirmative duty to disclose to FOF material fraud discovered in its audit. It was reasonable for the jury to conclude that AA acted with requisite scienter in disregarding knowledge and obvious risks to FOF....,75

The jury assessed damages in the tens of thousands of dollars. However, the district judge reduced the verdict to an undisclosed amount. More importantly for us, the jury also found AA guilty on the common law fraud and breach of contract charges. ${ }^{76}$ As to the subject matter of jurisdiction, the court stated, "...even more critical than the conduct of the King entities was the conduct of AA in providing accounting services to parties intimately involved in all phases of the case on both sides of every relevant transaction." ${ }^{, 77}$

While auditing FOF, AA was also auditing the King group, including John M. King himself. The audit leaders, both the partner-in-charge and the manager, were the same people on both the King Resources Company (KRC), a King affiliate, and the NRFA audit for FOF. Staffers in AA's Denver office sometimes worked on both audits at the same time. ${ }^{78}$ By doing this, AA was able to see the situation from differing points of view; FOF believed AA breached its contract when it failed to act on that knowledge.

In the charge to the jury, as to the overcharges which specified that King was to sell natural resource interests to FOF at a predetermined markup, the judge noted, "FOF contend[ed] that AA did not attempt to find out whether KRC's sales to FOF were made as agreed..." and "[m]oreover, when the comparative figures of the King group's costs and sale prices became known to AA, AA was allegedly required to either disclose such matters to FOF or resign at least one account." AA, on the other hand, "contend[ed] that the duty of confidentiality prohibited disclosure or that FOF's proposed alternative that AA should resign would not have better informed FOF." 79

On the issue of breach of contract, the district judge summarized that FOF charged AA with breach of contract when it failed to disclose irregularities it discovered when the contract of engagement "...specifically required AA to bring to FOF's attention any irregularities discovered in their audit and pledged AA to use due care in conducting their audits in accordance with generally accepted auditing standards ('GAAS')."

\footnotetext{
${ }^{74}$ Statements of Auditing Standards.

75 545 F. Supp. 1314, 1348.

${ }^{76}$ Ibid., Memorandum Decision.

${ }^{77}$ Ibid., 1348.

${ }^{78}$ Ibid., 1332.

${ }^{79}$ Ibid., 1338.
}

(C) 2012 The Clute Institute http://www.cluteinstitute.com/ 
FOF contend[ed] that AA violated as many as seven generally accepted auditing standards ('GAAS'): (1) AA had a conflict of interest and lacked independence (at least after it learned of the high markups and sales not in accordance with the FOF-KRC arrangements); (2) AA failed to exercise due care (especially with regard to the Arctic revaluation); (3) AA failed to alert FOF as to the defects in FOF's internal financial controls whereby such controls could not be relied upon by AA; (4) AA gathered inadequate evidence to support its opinion on the revaluation; (5) in violation of generally accepted accounting principles ('GAAP'), there was inadequate disclosure of the FOF/KRC transactions... [and] the inadequate internal controls...; (6) AA did not reveal all material matters in the financials...; and (7)it was inappropriate not to qualify the FOF and FOF Prop financial statements as of December 31, 1968, and June 30, 1969, and a disclaimer or adverse opinion should have been made in the FOF... statements as of December 31, 1969. ${ }^{80}$

Even though AA denied both that it had committed common law fraud or a breach in any way, the jury saw things differently.

Recovery from common law fraud is "based upon a material misrepresentation made with scienter which induces reliance to the detriment of the party to whom the misrepresentation is directed." liable for common law fraud following the judge's charge that ..."'the requirement of a 'misrepresentation' is satisfied where the defendant has failed to disclose facts necessary to keep other statements that it did make from being misleading or where the defendant fails to disclose information despite a relationship of trust and confidence with the plaintiffs." 82

AA tried to argue that FOF did not have the right to know King's cost of the natural resource investments. That information, AA claimed, was confidential. Once again, the jury did not see it that way, especially when it considered that records from the King group were used for the NRFA audits of FOF. If AA did indeed have a duty of confidentiality, at a minimum, AA should have "(1) strongly encourage[d] one client to make the necessary disclosure, (2) disclose[d] that it ha[d] relevant information not available to the other client, or (3) resign[ed] from one account." ${ }^{83}$ Given that AA did not do any of these, the jury felt that AA failed to perform its duty.

Responding on the issue of breach of contract, AA first tried to argue that Swiss law should be followed because the initial letter of engagement was sent from the Zurich office. Failing that, AA then tried to argue that a breach of contract is a type of malpractice claim with a three-year statute of limitation, which had passed some time before. A contract, on the other hand, would have had a six-year statute of limitation. Earlier cases, such as Carr v. Lipshire and Adler \& Topal, P.C. v. Exclusive Envelope, supported the position that cases on audit services must be filed within three years if the parties were performing general auditing services. ${ }^{84}$

The court suggested that the engagement letter between AA and FOF was more detailed than normally found and that, consequently, "AA may have had a general duty to watch out for fraud and to exercise its professional judgment in deciding how to deal with fraud if it was discovered, but the engagement letter specifically obligated[d] AA to disclose to FOF any irregularities that it discovere[d]." ${ }^{.85}$

Again, AA's own words made its position more difficult. Later correspondence between AA and FOF indicated that AA was to determine whether revaluations of natural resource investments sold by the King group to FOF were in accordance with the agreement between the mutual fund and its investment advisor. This made the agreement a contract and subject to the longer statute of limitation. AA's argument "...that the jury 'should have been instructed to consider the fact that these plaintiffs were highly sophisticated businessmen" seemed to hold little weight with the judge. Judgment was against AA on both the common law fraud and breach of contract charges.

\footnotetext{
${ }^{80}$ Ibid., 1338.

${ }^{81}$ Ibid., 1357.

${ }^{82}$ Ibid., 1357.

${ }^{83}$ Ibid., 1357.

${ }^{84}$ Carr v. Lipshire, 8 App. Div.2d 330, 187 N.Y. S.2d 564 (1 ${ }^{\text {st }}$ Dept. 1959), aff'd 9 N.Y.2d 983, 218 N.Y.S.2d 62 (1961) and Adler \& Topal, P.C. v. Exclusive Envelope Corp., 84 App.Div.2d, 365, 367-68, 446 N.Y.S.2d 337, 338-39, (2d Dept. 1982) cited in 545 F. Supp. 1314, 1357.

85545 F. Supp. $1314,1357$.
} 
Regarding the revaluations, AA's own work papers and correspondences showed knowledge of what was happening among the related parties. During the trial, it was shown that AA auditors found it "unusual" that "in each and every natural resource transaction, the interest purchased was a portion of an interest previously or contemporaneously owned by a member of the King group", while at the same time the King group represented itself as an investment advisor to FOF. It was shown that in addition to having access to information on the "special inventory" of natural resource investments that had been sold to FOF by King for use in valuing FOF shares, AA would have seen that the FOF investments in natural resource differed from its other investments in that each one was, or had been, a portion of an investment owned by King or an affiliate. ${ }^{86}$

How did AA get into this situation? AA chose to do audit work for too many related parties. By doing so, it was able to see the books and records of all parties involved. "In addition to auditing FOF, AA audited the King group, including KRC, TCC, and John M. King personally. AA's Denver office performed the King audits and did substantial work on the NRFA audit for FOF. The partner in charge and the manager of the KRC audit held the same positions with respect to the NRFA audit. The NRFA audit was performed by using the records of KRC, and sometimes AA staffers would work on KRC and NRFA audits simultaneously." ${ }^{\prime 7}$ The desire for revenues overcame the firm's desire to follow the spirit of GAAS. Even when it found "unusual" or suspicious transactions and arrangements among the parties, AA did not take the initiative to drop one or more of the parties. As a result, it found itself as the exemplar in auditing texts as to what the toll failure to maintain confidentiality can take on a firm. The lesson was a costly - and avoidable - one.

\section{AUTHOR INFORMATION}

A. Bruce Strauch is a Professor of Business Law at The Citadel. He is a member of the N.C. and S.C. Bars, the U.S. Fourth Circuit and Fourth Circuit Court of Appeals. He is the publisher of the journal Against the Grain, and owner of the Charleston Conference. E-mail: bruce.strauch@citadel.edu

Sheila D. Foster is Professor of Accounting at The Citadel. She has earned a B.S. from Radford College, a M.Ed. and a CIA from Virginia Commonwealth University, and a Ph.D. in Accounting from Virginia Tech. Dr. Foster is a Certified Public Accountant and a Certified Fraud Examiner. E-mail: FosterS@Citadel.edu (Corresponding author)

\section{REFERENCES}

1. "Bernie Cornfeld: Ran Ill-Fated IOS Fund," Los Angeles Times, March 1, 1995, http://articles.latimes.com/print/1995-03-01/news/mn-37394_1_bernie-cornfeld

2. "Bernard Cornfeld," Wikipedia, http://en.wikipedia.org/wiki/Bernard Cornfeld

3. "Code of Professional Conduct." American Institute of Certified Public Accountants, 1988.

4. Herzog, Arthur. Vesco: From Wall Street to Castro's Cuba: The Rise, Fall, and Exile of the King of White Collar Crime. New York: Doubleday, 1987.

5. Hutchinson, Arthur. Robert A. Vesco. New York: Praeger, 1974.

6. "Mutual Funds: Those I.O.S. Loans," Time, June 22, 1970, www.time.com/timemagazine/article/0.9171.944112.00html

7. "Robert Vesco," The Economist, May 31, 2008, Vol. 387, Issue 8582.

8. "Statements on Auditing Standards (SASs)." American Institute of Certified Public Accountants, Audition Standards Board, 1973.

9. The Fund of Funds, Limited, FOF Proprietary Funds, Ltd, and IOS Growth fund, Limited, a/k/a Transglobal Growth Fund, Limited Plaintiffs, v. Arthur Andersen \& Co., Arthur Andersen \& Co. (Switzerland), and Arthur Andersen \& Co., S.A., Defendants, 545 F. Supp. 1314.

10. "The Inductees: Bernie Cornfeld," Con Artist Hall of Infamy, www.thehallinfamy.org/inductees.php?actiondetail\&artist+bernard_Cornfeld

11. Trumbore, Brian. "The Fund Industry's Black Eye," Buy and Hold, http://www.buyandhold.com/bh/enn/education/history/2002/fund.html

${ }^{86}$ Ibid., 1329.

Ibid., 1332.

C 2012 The Clute Institute http://www.cluteinstitute.com/ 
12. "Western Europe: The Return of Bernie Cornfeld," Time, April 23, 1965, www.time.com/time/printout/0,8816,833671,00.html 